\title{
BAHASA DAN KEBENARAN MENURUT JOHN LANGSHAW AUSTIN
}

\section{A. Widyarsono*}

\begin{abstract}
Abstrak: John Langshaw Austin menjadi terkenal sebagai filosof Lingkaran Oxford yang menekankan pentingnya tuturan performatif. Namun dalam artikelnya "Truth" (1950) ia menggunakan teori korespondensi dalam memahami masalah kebenaran. Austin mengkritik Strawson yang menggunakan teori deflasioner tentang kebenaran berdasarkan analisis mengenai pentingnya tuturan performatif. Dalam tulisan ini akan dijelaskan mengapa Austin lebih memilih teori korespondensi dari pada teori deflasioner dalam memahami kebenaran. Juga akan ditunjukkan sumbangan khas Austin yang membarui teori korespondensi umum yang menggunakan metafora "cermin" dan "peta" realitas dengan menekankan sifat konvensional ide korespondensi. Menurut penulis, hal ini merupakan suatu usaha yang serius dan berguna dalam mengartikulasikan cara kita menggunakan simbol-simbol bahasa yang ditentukan secara sewenang-wenang untuk merepresentasikan realitas dunia.
\end{abstract}

Kata-kata Kunci: Kebenaran, teori korespondensi, teori koherensi, teori deflasioner, teori tindak-tutur, aspek ilokusioner bahasa, tuturan deskriptif, tuturan performatif, konvensi deskriptif, konvensi demonstratif.

\begin{abstract}
John Langshaw Austin is an "Ordinary Language Philosopher" of Oxford, who is famous for emphasizing the importance of performative statements. In his article, "Truth" (1950), however, he used correspondence theory for understanding the problem of truth. Austin criticized Strawson, who uses the deflationary theory of truth that is compatible with the analysis of performative utterances. This article will explain why Austin chooses the correspondence theory of truth rather than deflationary one. It will also elaborate Austin's specific contribution in
\end{abstract}

* A. Widyarsono, Program Studi Ilmu Filsafat, Sekolah Tinggi Filsafat Driyarkara, Cempaka Putih Indah 100 A, Jembatan Serong, Rawasari, Jakarta 10520. Email: awidya@gmail.com. 
changing the version of the correspondence theory, which uses the metaphor of "mirroring" or "mapping"' the world, to a conventional correspondence theory. It is, in my opinion, a serious and notable attempt to articulate our use of arbitrary symbols in the representation of brute reality.

Keywords: Truth, correspondence theory, coherence theory, deflationary theory, speech-act theory, the illocutionary aspect of language, descriptive utterance, performative utterance, descriptive convention, demonstrative convention.

\section{PENDAHULUAN}

“Apa itu kebenaran?" Inilah pertanyaan Pilatus yang digunakan oleh John Langshaw Austin untuk membuka artikelnya, "Truth," yang ditulis pada 1950. ${ }^{1}$ Austin langsung berkomentar bahwa "Pilatus berada lebih dahulu dari zamannya,"2 karena masalah "kebenaran" adalah masalah filosofis yang dari zaman ke zaman selalu dibicarakan. Menarik untuk melihat bagaimana seorang tokoh Lingkaran Oxford yang berfilsafat dengan menggunakan analisis penggunaan bahasa sehari-hari merefleksikan masalah metafisis seperti kebenaran ini. Austin terkenal dengan pendekatan linguistiknya yang membuka perspektif tuturan yang tidak dibatasi pada tuturan deskriptif seperti kaum positivis logis, tetapi juga bermacam-macam tuturan lain seperti tuturan performatif. Apakah masalah benar atau salah akan dipahami tetap dalam konteks tuturan deskriptif atau performatif? Bagaimana dia secara epistemologis menghubungkan masalah kebenaran dengan fakta dan pernyataan?

1 John Langshaw Austin, "Truth," Proceedings of the Aristotelian Society, Suppl. 24 (1950), pp. 111-128; reprinted in John Langshaw Austin, Philosophical Papers (Oxford: Oxford University Press, 1970), pp. 117-133. (Selanjutnya disingkat: Austin, "Truth." Di sini yang digunakan adalah versi tahun 1970). Artikel ini merupakan bagian dari Simposium mengenai "Kebenaran" yang juga diisi oleh Strawson dan Cousin. Dalam simposium itu Strawson mengkritik Austin yang kemudian ditanggapi Austin dalam artikel "Unfair to Facts" (1954). Artikel "Truth" ini kemudian muncul dalam kumpulan karangan Philosophical Papers, pp. 117-133, yang diedit oleh Urmson dan Warnock dan diterbitkan pada 1961, setelah Austin meninggal. Artikel "Truth" ini merupakan tanggapan Austin atas tulisan Strawson sebelumnya, "Truth" (1949).

2 Austin, "Truth," p. 117. 
Apakah teori kebenaran yang digunakannya adalah teori korespondensi, koherensi atau deflasioner (the deflationary theory)?

Austin adalah seorang tokoh pendiri dan motor filsafat analitik yang berkembang di Oxford setelah Perang Dunia II yang kemudian dikenal sebagai Lingkaran Oxford. Austin yang meninggal dalam usia yang relatif muda memang tidak pernah mempublikasikan buku yang utuh, namun pengaruhnya sangat besar bagi para filosof yang sering berdiskusi bersama dengannya. Salah satu sumbangan besar Austin dan Lingkaran Oxford adalah memperluas kesadaran orang tentang adanya bermacammacam tuturan. Mereka menolak reduksi dan asimilasi tuturan pada model tertentu. Yang mereka tolak adalah aliran positivisme-logis yang mereduksikan bentuk tuturan pada pernyataan deskriptif yang dapat ditentukan nilai benar atau salahnya; artinya, bentuk tuturan lain dianggap tidak bermakna. Austin dan para koleganya menyatakan bah- wa bukan hanya tuturan deskriptif saja yang bermakna, melainkan juga tuturan performatif, askriptif, dan lain-lain.

Tulisan ini menguraikan pandangan Austin mengenai "kebenaran" dalam artikelnya yang terkenal, "Truth" (1950). Pertama-tama akan diuraikan tentang bagaimana Austin memiliki pengaruh yang sangat besar bagi Lingkaran Oxford. Kemudian akan dijelaskan hubungan antara bahasa dan filsafat menurut Austin. Baru setelah itu akan dijelaskan konsep dan teori kebenaran yang dikembangkan Austin dalam "Truth." Akhirnya artikel ini akan ditutup dengan memberi catatan kritis atas konsep kebenaran Austin tersebut.

\section{JOHN LANGSHAW AUSTIN DAN LINGKARAN OXFORD}

John Langshaw Austin lahir di Lancaster, Inggris, pada 26 Maret 1911 dan meninggal pada 1960, delapan tahun setelah diangkat menjadi “White's Professor of Moral Philosophy" di Oxford. Ketika Austin menjadi Profesor, ada sekitar enam puluh filosof profesional di Oxford, namun hanya ada tiga orang yang bergelar Profesor (dua yang lain adalah Gilbert Ryle dan H. H. Price). Menurut John A. Searle, mahasiswanya, "Austin adalah seorang yang paling berpengaruh dari suatu 
kelompok filosof Oxford yang sangat dihormati pada masa itu." ${ }^{3}$ Inilah kelompok yang kemudian dikenal sebagai Lingkaran Oxford ("Oxford Philosophy"). Menurut Hacker, Lingkaran Oxford ini merupakan fase keempat perkembangan filsafat analitik yang dipimpin oleh Austin dan Ryle dengan dibantu oleh para kolega mereka seperti Waisman, Grice, Hart, Hampshire, dan Berlin, serta generasi setelah perang seperti Strawson dan Hare. ${ }^{4}$ Pada dekade 1950-an itu kebanyakan orang di Oxford berpikir bahwa Oxford adalah universitas terbaik di dunia untuk bidang filsafat dan memang filsafat adalah bidang paling dominan di universitas itu secara keseluruhan. Dalam pusat pusaran pengaruh Lingkaran Oxford itu adalah figur Austin yang sangat dihormati baik oleh para mahasiswa dan koleganya di Lingkaran Oxford, maupun di universitas secara umum. ${ }^{5}$

3 John R. Searle, "J. L. Austin (1911-1960)" in A Companion to Analytic Philosophy, eds. A. P. Martinich \& D. Sosa (Oxford: Blackwell, 2001), p. 218.

4 Lih. P. M. S. Hacker, "Analytic Philosophy: what, whince, and whither?" in The Story of Analytic Philosophy: Plot and Heroes, eds. A. Biletzki, \& A. Matar (London: Routledge, 1998), p. 22. Dalam artikel itu Hacker membagi perkembangan filsafat analitik dalam empat fase. Fase pertama adalah fase pemberontakan Russel dan Moore di Cambridge melawan dominasi idealisme pada tahun 1890-an. Fase kedua adalah analisis Cambridge pada tahun 1920-an dan awal 1930-an yang sangat dipengaruhi oleh Moore dan Russel dan mendapat inspirasi dari karya Wittgenstein, Tractatus (misalnya, Ramsey, Braithwaite, Wisdom, dan Stebbing). Fase ketiga adalah empirisme logis lingkaran Wina yang juga mendapat inspirasinya dari Tractatus. Fase keempat adalah Lingkaran Oxford dengan analisis bahasa sehari-hari yang berkembang sejak 1945 dengan tokohtokohnya seperti Ryle, Austin, Waismann, Hart, Hampshire, dan Berlin. Pengaruh fase keempat ini menurun pada tahun 1970-an dengan kuatnya pengaruh pragmatisme logis Amerika Serikat dengan tokoh-tokoh seperti Quine dan Davidson. Lih. P. M. S. Hacker, "Analytic Philosophy," pp. 14-24.

5 Untuk memberi ilustrasi mengenai besarnya pengaruh Austin ini dapat disebut kasus pengangkatan H. L. A. Hart sebagai Profesor Yurisprundensi di Oxford. Pada 1952, atas anjuran Austin, Hart menjadi Profesor Yurisprudensi menggantikan Prof. A. L. Goodhart. Hart sebenarnya memiliki kontak yang sangat terbatas dengan Fakultas Hukum Universitas Oxford. Maka pengangkatannya sebagai Profesor Yurisprudensi merupakan hal yang tak terduga dan mengejutkan, baik bagi Hart sendiri maupun bagi para anggota Fakultas Hukum. Bayangkan saja bahwa Hart pada saat itu belum menghasilkan karya yang sangat berarti, dan ia sebenarnya lebih dikenal di kalangan filsafat, lebih-lebih di dalam Lingkaran Oxford, dari pada di lingkungan Fakultas Hukum. Menurut Lacey, peristiwa bahwa Hart dipandang sebagai kandidat yang pantas untuk kursi Profesor Yurispudensi, dan bahkan kemudian mendudukinya, merupakan bukti "kekuatan institusional Austin, status filsafat, dan pentingnya di Oxford saat itu memiliki suatu reputasi keunggulan dalam seminar-seminar dan perbincangan-perbincangan informal." Lih. Nicola Lacey, A Life of H. L. A. Hart: The Nightmare and the Noble Dream (Oxford: Oxford University Press, 2004), p. 149. 
Menurut Searle, pengaruh Austin bukan pertama-tama karena karya tertulisnya. Dilihat dari publikasi karya-karyanya, sebenarnya Austin tidaklah tergolong sebagai filosof yang produktif. Ia hanya mempublikasikan tujuh artikel selama hidupnya, yang kemudian diterbitkan dalam buku Philosophical Papers pada 1961, setelah kematiannya. ${ }^{6}$ Selain Philosophical Papers, ada dua buku lain yang diterbitkan oleh para muridnya setelah Austin meninggal, yakni How to Do Things with Words (1962), dan Sense and Sensibilia (1962). Buku kedua berasal dari "William James Lectures" yang diberikan Austin pada 1955 di Harvard, dan salah satu versinya diterbitkan sebagai buku. Sementara itu, buku ketiganya adalah kumpulan kuliah yang direkonstruksikan dari manuskrip yang ada oleh G. J. Warnock.

Menurut Searle, ada dua faktor yang membuat pengaruh Austin sedemikian besar. Pertama, Austin memiliki suatu ide yang orisinal mengenai bagaimana filsafat harus dilakukan. Kedua, ia memiliki intelektualitas dan kepribadian yang kuat yang dapat nampak di mimbar kuliah, namun terutama dalam diskusi-diskusi filosofis, baik bagi para mahasiswa, maupun kolega dosennya. ${ }^{7}$ Faktor kedua ini nampak dalam diskusi-diskusi informal yang dilakukannya bersama dengan para kolega dosen. Stuart Hampshire, koleganya, menceritakan bahwa pada masa sebelum Perang Dunia II (1936-1939) “Austin datang dalam diskusi mingguan informal yang dilakukan di kantor Berlin, bersama dengan Ayer, Woozley, MacNabb, dan saya sendiri." ${ }^{8}$ Hampshire menyebutkan bagaimana peranan dan pengaruh pemikiran Austin sangat nampak

6 Ketujuh artikel itu adalah "Are There A Priory Concepts?" (1939), "Other Minds" (1946), "Truth" (1950), “How to Talk-some simple ways" (1953), "Ifs and Cans" (1956), "A Plea of Excuses" (1956), dan "Pretending" (1958). Tiga artikel pertama dan terakhir adalah sumbangan pemikirannya dalam diskusi ilmiah yang diadakan oleh "Mind Association" dan "Artistotelian Society" yang kemudian diterbitkan dalam volume tambahan jurnal Proceedings of the Aristotelian Society. Artikel kelima (1956) diterbitkan dalam Proceedings of the British Academy. Yang keenam adalah pidato ilmiahnya sebagai Presiden "Aristotelian Society" pada 1956. Bersama artikel keempat, artikel keenam diterbitkan dalam Proceedings of the Aristotelian Society. Lih. John Langshaw Austin, Philosophical Papers, p. xvi.

7 Lih. John A. Searle, “J. L. Austin (1911-1960),” p. 219.

8 Stuart Hampshire, "J. L. Austin (1911-1960)," Proceedings of the Aristotelian Society, New Series 60 (1959-1960), p. XII. 
dalam diskusi-diskusi informal semacam ini. ${ }^{9}$ Setelah Perang Dunia II, Austin melanjutkan kebiasaan mengadakan diskusi informal pada hari Sabtu pagi di kantornya bersama para kolega dosen yang kebanyakan lebih muda darinya. ${ }^{10}$ Dari forum informal inilah pengaruh Austin dapat bertahan setelah ia meninggal.

Apakah yang menjadi kekhasan Lingkaran Oxford dan pendekatannya? Morris Weitz, yang menulis artikel "Oxford Philosophy" pada 1953, mengemukakan bahwa salah satu ciri khas Lingkaran Oxford adalah bahwa mereka tidak memiliki manifesto, doktrin, atau slogan bersama. ${ }^{11}$ Mereka meninggalkan analisis model matematis yang dimulai oleh $\mathrm{B}$. Russell dan mencoba memahami logika di dalam dan melalui konsepkonsep dalam penggunaannya sehari-hari. Itulah sebabnya pendekatan mereka sering disebut sebagai "ordinary language philosophy" (filsafat bahasa sehari-hari); artinya, fokus mereka adalah pada penggunaan sehari-hari konsep-konsep dan ungkapan-ungkapan dalam bahasa, misalnya, "melihat," "mengetahui," "benar," karena dari sanalah muncul masalah filosofis. Namun harus dicatat bahwa fokus mereka bukanlah pada linguistik, melainkan karakter logis ekspresi (bahasa). Mungkin karena itu, maxim mereka yang terkenal adalah "setiap pernyataan

9 Stuart Hampshire menceritakan bahwa Austin dalam diskusi informal semacam ini "menantang setiap konsep teknis sebagai bagian dari mitologi filosofis." Stuart Hampshire, “J. L. Austin (1911-1960)," p. xii. Suasana filosofis pada masa sebelum Perang Dunia II ini adalah suasana kritis atas konsep-konsep teknis dari Lingkaran Wina, maka tidak mengherankan kalau dalam forum ini terjadi diskusi yang panas antara Austin dan Ayer (tokoh Lingkaran Wina).

10 Lacey memberikan ilustrasi menarik mengenai bagaimana Hart dan para dosen muda lain terlibat dalam diskusi filosofis pada hari Sabtu pagi di kamar Austin. Kelompok yang dibentuk pada 1947 dengan Hart sebagai salah satu pendirinya praktis merupakan kelompok yang mendalami dan menyebarkan metode dan ide-ide filsafat bahasa sehari-hari gaya Austin. Diskusi dipimpin sendiri oleh Austin dengan metode analitis yang sangat rigor dan teliti. Lih. Nicola Lacey, A Life of H. L. A. Hart, pp. 133-136. Para dosen muda yang terlibat dalam kelompok ini selain Hart adalah F. Waismann, G. A. Paul, J. O. Urmson, A. D. Woozley, R. M. Hare, P. F. Strawson, Geoffrey, Mary Warnock, Philipa Foot, dan A. M. Honore. Lih. Neil McCormick, H. L. A. Hart (Stanford: Stanford University Press, 2008), pp. 5-6. Tentang bagaimana Lingkaran Oxford yang dipimpin Austin ini menjalankan diskusinya diceritakan secara lengkap oleh seorang pengikut setianya, G. J. Warnock. Lih. G. J. Warnock, "Saturday Mornings" in I. Berlin et. al., Essays on J. L. Austin (Oxford: Oxford University Press, 1973), pp. 31-45.

11 "These philosophers issue no manifestoes and they sign no petitions." Morits Weitz, "Oxford Philosophy," The Philosophical Review 62 (1953): 187. 
mempunyai logikanya sendiri;" artinya, mereka menolak reduksi dan asimilasi pernyataan pada model tertentu. Dalam hal ini mereka menolak asumsi aliran positivisme-logis yang mereduksikan bentuk tuturan pada pernyataan deskriptif yang bisa ditentukan nilai benar/salahnya. Maka bentuk tuturan lain dianggap sebagai tidak bermakna.

Dengan kata lain, tujuan dari pendekatan mereka adalah, pertama, mendeskripsikan logika penggunaan sehari-hari konsep atau ungkapan yang relevan bagi masalah filosofis; kedua, menunjukkan bahwa solusi konkret bagi problem filosofis diperoleh dengan menjernihkan penggunaan konsep atau ungkapan yang sehari-hari dianggap sebagai konsep baku. Dengan pendekatan ini mereka berusaha memperluas klasifikasi skema tuturan: fungsi bahasa bukan hanya deskriptif, tetapi jauh lebih luas seperti performatif, askriptif, dan seterusnya. Dalam fase filsafat analitik sebelumnya, tuturan hanya dibagi menjadi tuturan deskriptif dan emotif, artinya, yang dianggap penting dan bermakna oleh penganut positivisme-logis hanyalah yang pertama. Namun Lingkaran Oxford, khususnya Austin, menunjukkan dalam "speech-act theory"-nya ("teori tindak-tutur") tentang pentingnya tuturan performatif dalam kehidupan manusia. Dengan tuturan performatif kita tidak semata-mata melukiskan suatu perbuatan melainkan melakukannya. Tuturan performatif ini nampak dalam kalimat seperti "aku berjanji" dan "aku tahu." Jenis tuturan ini tidak dapat dimasukkan dalam klasifikasi tuturan yang dibuat aliran positivisme-logis: bukan tuturan deskriptif atau emotif. Dalam tuturan performatif yang penting bukanlah nilai benar/salah suatu tuturan seperti dalam model deskriptif, melainkan sah/tidaknya tuturan. ${ }^{12}$

Menurut Weitz, peralihan fokus Lingkaran Oxford pada analisis penggunaan sehari-hari bahasa/konsep itu juga membawa peralihan radikal dalam mengajukan pertanyaan filosofis: "apakah hakikat ' $X$ '?"

12 Hart, misalnya, menunjukkan bekerjanya tuturan performatif ini dalam dunia legal yang disebutnya sebagai "tuturan askriptif," yang berarti tuturan yang menyertakan hak atas pemilikan atau melekatkan tanggung jawab atas tindakan. Hart terutama menunjukkan kekhasan tuturan askriptif dalam dunia hukum yang masalahnya bukan benar/salah seperti dalam tuturan deskriptif, melainkan dapat dibatalkan atau tidak. Lih. Moritz Weitz, “Oxford Philosophy," pp. 187-233. 
(misalnya pengetahuan, kebenaran, kewajiban) atau "apakah makna ' $X$ '?" kepada "apa saja penggunaan baku atau fungsi ' $X$ '?"13 Lingkaran Oxford yakin bahwa pertanyaan terakhir ini adalah cara yang paling menjanjikan untuk memecahkan suatu masalah filosofis. Misalnya, salah satu cara untuk menentukan "apakah pengetahuan itu?" adalah menentukan apakah penggunaan aktual dari kata kerja "tahu" dan "tahu bahwa" serta "tahu bagaimana?" Meskipun menjelaskan penggunaan baku " $X$ " mungkin bukan tujuan akhir kegiatan filsafat, Austin yakin bahwa hal ini adalah awal kegiatan itu. ${ }^{14}$

\section{BAHASA DAN FILSAFAT MENURUT JOHN LANGSHAW AUSTIN}

Telah kita lihat di atas bahwa bagi Lingkaran Oxford, kegiatan filsafat harus dimulai dari analisis penggunaan bahasa sehari-hari; maka mungkin baik secara singkat kita membahas beberapa pandangan Austin mengenai relasi antara bahasa dan filsafat. Pertama-tama akan diuraikan pandangan Austin mengenai peranan analisis bahasa dalam filsafat. Lalu akan disampaikan kekhasan pendekatan Austin yang menekankan perlunya analisis penggunaan bahasa sehari-hari itu diterapkan juga dalam tema-tema filsafat. Apa bahayanya jika hal ini tidak dilakukan? Akhirnya bagian ini diakhiri dengan meringkas pandangan Austin mengenai peranan bahasa sehari-hari pada filsafat.

Bagaimana pandangan Austin mengenai peranan analisis mengenai bahasa dalam filsafat? Menurut Guy Longworth, ada dua alasan mengapa Austin memfokuskan diri pada penelitian mengenai bahasa. Pertama, penggunaan bahasa merupakan bagian sentral dari kegiatan manusia. Kedua, penelitian bahasa merupakan suatu alat pendukung-untuk beberapa bidang bahkan menjadi suatu studi pendahuluan yang mutlak perlu-untuk memahami topik-topik filsafat. ${ }^{15}$

13 Moritz Weitz, "Oxford Philosophy," p. 188.

14 Moritz Weitz, “Oxford Philosophy," p. 189.

15 Guy Longworth, "John Langshaw Austin," in The Stanford Encyclopedia of Philosophy, ed. Edward N. Zalta (Summer Edition 2013). http://plato.stanford.edu/archives/ sum2013/entries/austin-jl/, pp. 1-4. Diunduh pada 10 September 2013. 
Bagaimana pendekatan Austin sebagai seorang filosof menggunakan bahasa sebagai alat pendukung dalam filsafat? Mengenai pendekatan Austin ini, Hampshire, kolega dekatnya, mengatakan:

[Austin] secara konstitusional tidak mampu menghindari untuk menggunakan standar-standar yang sama dari kebenaran dan ketepatan pada suatu argumen filosofis, kalimat demi kalimat, seperti ia akan menggunakannya untuk masalah-masalah serius yang lain. Ia tidak mungkin dapat menerapkan suatu suara yang khusus, atau sikap mental tertentu untuk pertanyaan-pertanyaan filosofis. ${ }^{16}$

Yang mau dikatakan Hampshire dari kutipan di atas adalah bahwa pentinglah bagi para filosof, menurut Austin, untuk memenuhi kriteria bahasa sehari-hari berkaitan dengan kebenaran, ketepatan, dan sebagainya, pada saat mereka mengemukakan posisi atau argumentasi filosofis mereka. Kriteria bahasa sehari-hari mengenai kebenaran dan ketepatan bagi pernyataan-pernyataan kita seharusnya peka terhadap nuansanuansa yang halus dari makna dan penggunaan bahasa.

Dengan kata lain, Austin menekankan pentingnya memahami nuansa-nuansa halus yang ada dalam penggunaan bahasa sehari-hari sebelum diterapkan dan digunakan dalam filsafat. Mengapa Austin menekankan pentingnya hal ini dalam metode berfilsafatnya? Setidaktidaknya, menurut Longworth, Austin melihat dua bahaya kalau kita tidak peka terhadap nuansa-nuansa itu. Pertama, para filosof bertanggungjawab atas ketidakmampuan membeda-bedakan nuansa kata atau ungkapan dalam bahasa sehari-hari yang sebenarnya relevan dengan keprihatinan dan klaim-klaim filosofis mereka. Kedua, kegagalan untuk memanfaatkan secara penuh kekayaan bahasa sehari-hari dapat menyebabkan kita rentan terhadap pilihan-pilihan yang tidak dapat dihindari atas alternatif yang tidak dapat diterima. ${ }^{17}$ Austin memperingatkan:

Adalah baik untuk diingat ... aturan umum bahwa kita tidak harus mengharapkan untuk menemukan label-label sederhana untuk kasus-

16 Stuart Hampshire, “J. L. Austin (1911-1960),” pp. I-II.

17 Guy Longworth, “John Langshaw Austin," p. 4. 
kasus yang sulit... bagaimanapun baiknya bahasa kita, hal itu tidak pernah dapat mempersenjatai kita dengan segala kemungkinan kasus yang dapat muncul dan harus dideskripsikan: fakta selalu lebih kaya dari pada diksi. ${ }^{18}$

Akhirnya, Austin meringkas pandangannya tentang peranan analisis bahasa sehari-hari dalam filsafat sebagai berikut:

Pertama, kata-kata adalah peralatan kita, dan, setidak-tidaknya kita seharusnya membersihkan peralatan kita itu: kita seharusnya tahu mengenai apa yang kita maksudkan dan apa yang tidak, kita harus mempersenjatai diri kita melawan jebakan-jebakan yang ada dalam bahasa. Kedua, kata-kata bukanlah (kecuali dalam sudut kecil mereka) fakta atau halnya sendiri; oleh karena itu kita perlu memisahkannya dari dunia, untuk memegangnya secara terpisah dan melawankannya dengan dunia, sehingga kita dapat menyadari keterbatasan dan kesewenang-wenangannya, dan dapat melihat kembali dunia tanpa bantuannya. Ketiga, dan yang lebih diharapkan, seluruh koleksi kata-kata itu yang biasa mewakili semua perbedaan yang ingin dilukiskan manusia, dan koneksi-koneksi yang perlu dibuatnya dalam kerangka waktu antargenerasi: koleksi katakata seperti ini nampaknya akan lebih berarti, karena mereka telah diuji lama sebagai yang paling dapat bertahan, dan lebih halus, sekurangkurangnya dalam segala hal praktis yang biasa dan dapat dipikirkan, dari pada hal-hal yang kita pikirkan secara spontan-metode alternatif yang paling disukai. ${ }^{19}$

Dari kutipan ini nampak betapa pentingnya peranan analisis bahasa sehari-hari dalam filsafat, setidak-tidaknya studi pendahuluan dalam bahasa merupakan hal yang diperlukan filsafat.

\section{KEBENARAN MENURUT JOHN LANGSHAW AUSTIN}

Masalah kebenaran merupakan masalah filosofis yang diperbincangkan dari zaman ke zaman. Bagaimana pandangan Austin dengan pendekatan filsafat bahasa sehari-hari mengenai masalah kebe-

18 John Langshaw Austin, "A Plea for Excuses: The Presidential Address," in Philosophical Papers, ed. John Langshaw Austin (Oxford: Oxford University Press, 1970), p. 195.

19 John Langshaw Austin, “A Plea for Excuses," pp. 181-182. 
naran? Bagian ini akan mencoba menguraikan pandangan Austin berdasarkan artikelnya yang terkenal, "Truth" (1950). Longworth mengatakan bahwa Austin membicarakan masalah kebenaran dalam berbagai macam kesempatan. Namun diskusi yang paling eksplisit mengenai hal ini adalah dalam artikel "Truth." ${ }^{20}$ Artikel ini sebenarnya merupakan tanggapan Austin atas artikel Strawson sebelumnya dengan judul yang sama, "Truth" (1949). Strawson berpendapat bahwa fungsi predikat "is true" ("adalah benar") adalah lebih performatif, karena menyatakan tindakan menyetujui atau mengafirmasi, dari pada deskriptif. Ia menuduh para lawannya telah melakukan "kesalahan deskriptif" (descriptive fallacy), yakni kesalahan untuk menilai suatu tuturan, atau bagian dari tuturan, yang jelas-jelas memiliki fungsi performatif sebagai tuturan yang (hanya) memiliki fungsi deskriptif. Menurut Strawson, predikat "adalah benar" secara logis berlebihan (logically superfluos). ${ }^{21}$ Salah satu tujuan Austin dalam artikelnya adalah melawan Strawson, yakni dengan membela pandangan bahwa predikat "adalah benar" tetap memiliki fungsi deskriptif (dan mungkin selain itu juga memiliki satu atau lebih fungsi performatif). Untuk mencapai tujuan tersebut Austin juga mengajukan beberapa pandangannya mengenai fungsi deskriptif dari predikat kebenaran itu. ${ }^{22}$

Untuk memahami isi artikel ini ada baiknya kita terlebih dahulu memahami secara singkat beberapa teori kebenaran (teori korespondensi, koherensi, dan deflasioner) untuk dapat menempatkan posisi Strawson dan Austin dalam kerangka teori kebenaran yang ada tersebut. Setelah itu akan diuraikan secara singkat bagaimana Austin membangun argumentasi dalam artikelnya dengan menunjukkan struktur artikel tersebut. Selanjutnya akan dijelaskan sumbangan khas Austin dalam artikel ini terhadap teori kebenaran tersebut dan bagaimana ia membangun argumentasinya untuk menunjukkan kekhasan sumbangannya itu. Akhir-

20 Lih. Guy Longworth, “John Langshaw Austin,” p. 6.

21 Itulah sebabnya Austin dalam salah satu bagian dalam artikelnya ini menanggapi secara mendalam argumen bahwa predikat "is true" itu secara logis berlebihan. Lih. John Langshaw Austin, "Truth," pp. 126-130.

22 Lih. Guy Longworth, “John Langshaw Austin," p. 6. 
nya, akan ditunjukkan pula argumentasi Austin melawan penganut teori deflasioner, termasuk Strawson.

\section{TEORI-TEORI Kebenaran}

Salah satu pertanyaan mendasar dalam teori kebenaran adalah apakah kebenaran itu atau apakah kriteria yang harus dipenuhi untuk menyebut sesuatu itu benar? ${ }^{23}$ Pertanyaan inilah, menurut Graham, yang menjadi fokus utama artikel Austin, "Truth." Austin merumuskannya, "kapan suatu pernyataan itu benar?"24 Setidak-tidaknya ada tiga teori kebenaran yang berusaha menjawab pertanyaan ini, yakni teori korespondensi, koherensi, dan deflasioner. ${ }^{25}$

Austin mengatakan bahwa jawaban spontan yang cenderung diberikan atas pertanyaan itu adalah "ketika hal itu sesuai (berkorespondensi) dengan fakta." 26 Dapat dikatakan bahwa setiap pernyataan bertujuan untuk mengatakan sesuatu tentang dunia, untuk menyatakan sejumlah fakta mengenainya. Jika ada suatu fakta dalam dunia yang sesuai dengan apa yang dinyatakan itu, maka penilaian itu benar. Inilah inti dari teori korespondensi. Yang implisit dalam teori ini adalah dakuan pernyataan dalam bentuk "adalah benar bahwa kucing itu ada di matras" secara positif membutuhkan analisis karena penampakan luarnya dapat menyesatkan. Artinya, dalam membuat pernyataan itu saya mungkin seolah-olah hanya memberikan sifat kebenaran yang sederhana pada penilaian "kucing itu ada di atas matras." Hal ini berarti bahwa untuk melakukan verifikasi atas apa yang saya katakan, kamu harus memutuskan penilaian itu sendiri, apakah memiliki sifat kebenaran itu atau tidak. Apa yang diimplikasikan oleh teori korespondensi ini, menurut Graham, bukanlah suatu sifat sederhana semacam itu, melainkan sifat relasional. Artinya, kebenaran suatu pernyataan bukanlah sesuatu yang "internal"

23 Lih. Keith Graham, J. L. Austin: A Critique of Ordinary Language Philosophy (Hassocks, Susssex: The Harvester Press, 1977), p. 185.

24 John Langshaw Austin, “Truth," p. 121.

25 Untuk menguraikan secara singkat ketiga teori kebenaran ini penulis mendasarkan diri pada buku Keith Graham, J. L. Austin, pp. 186-188.

26 John Langshaw Austin, “Truth,” p. 121. 
di dalam pernyataan itu, melainkan kebenarannya terletak dalam suatu relasi khusus dengan sesuatu yang lain, atau secara kasar suatu hal dari dunia. $^{27}$

Salah satu cara memahami teori koherensi, menurut Graham, adalah melihatnya sebagai suatu reaksi atas beberapa masalah dalam teori korespondensi. Ada yang mengatakan bahwa konfrontasi telanjang antara penilaian dan dunia yang diimplikasikan oleh teori korespondensi hanyalah suatu ilusi. Jika saya harus menilai kebenaran pendapat bahwa "kucing itu ada di atas matras," maka segala sesuatu mengenai dunia yang relevan dengannya akan sudah diungkapkan dalam bentuk tertentu pendapat itu: bahwa ada seekor kucing dengan deskripsi tertentu di suatu tempat, bahwa saya harus melihat hal tertentu itu jika saya melihatnya pada arah tertentu, dan seterusnya. Maka mungkin dapat disimpulkan bahwa kebenaran dari suatu pendapat paling baik dipahami tidak sebagai suatu relasi antara pendapat itu dengan sesuatu yang berbeda bentuk eksistensinya, melainkan sebagai suatu relasi antara pendapat itu dengan sesuatu yang setara, yakni pendapat-pendapat yang lain. Maka dalam teori koherensi dikatakan bahwa kebenaran suatu pendapat terletak dalam koherensinya dengan pendapat-pen-dapat yang lain. ${ }^{28}$

Persamaan kedua teori kebenaran di atas adalah keduanya mendaku bahwa kebenaran adalah sesuatu yang relasional. Teori yang ketiga, teori deflasioner, ${ }^{29}$ bergerak secara drastis ke arah yang bertolak belakang dari keduanya. Yang menjadi ciri khas teori ketiga ini adalah bahwa dalam pernyataan, " $\mathrm{p}$ is true" atau "it is true that $\mathrm{p}$," frase "is true" adalah

27 Lih. Keith Graham, J. L. Austin, p. 187.

28 Lih. Keith Graham, J. L. Austin, p. 187.

29 Ada bermacam-macam nama untuk teori ketiga ini: "the deflationary theory," "the redundancy theory," "the disappearance theory," "the no-truth theory," "the disquotational theory," and "the minimalist theory." Lih. D. Stoljar \& N. Damnjanovic, "The Deflationary Theory of Truth" in The Stanford Encyclopedia of Philosophy, ed. Edward N. Zalta (Summer Edition, 2012). http:// plato.stanford.edu/archives/sum2012/entries/truthdeflationary/. Diakses pada 10 September 2013. Tidak ada konsensus mengenai penggunaan nama-nama itu. Graham, misalnya, lebih memilih istilah "the redundancy theory." Dalam tulisan ini penulis menerjemahkannya dengan istilah "teori deflasioner" yang memang menggunakan kata sifat yang sudah lebih jamak digunakan dalam bahasa Indonesia seperti istilah "inflasioner." 
berlebihan secara logis. Informasi yang dimuat oleh pernyataan " $\mathrm{p}$ is true" tidak berbeda dengan, dan tidak lebih besar dari pada informasi yang dimuat oleh " $p$. " Dalam arti ini, kebenaran secara logis adalah konsep yang deflasioner, yang disempitkan (dimampatkan).

Yang mau dikritik oleh teori deflasioner adalah klaim kebenaran dalam pernyataan "Adalah benar bahwa Akhmad lelah." Namun kritik ini langsung memunculkan pertanyaan: jika pernyataan itu tidak ada bedanya dengan "Akhmad lelah," dalam arti informasi yang dimuatnya, bagaimana mungkin kita masih memerlukan konsep kebenaran, atau kata-kata seperti "benar" dalam bahasa kita? Apakah hal ini hanya sekedar suatu langkah penggandaan yang tidak perlu, dan bagaimana mungkin hal ini terjadi dalam banyak bahasa? Untuk menjawab pertanyaan ini para penganut teori deflasioner memberikan peran bagi konsep kebenaran, namun masih dalam batas pemahaman teori mereka. Mereka, misalnya, mengatakan bahwa kalau saya berkata, "Adalah benar bahwa Akhmad lelah," saya sama sekali tidak membuat pernyataan baru di luar atau melebihi pernyataan "Akhmad lelah." Meskipun demikian, saya membuat pernyataan dengan cara yang khusus yang membutuhkan konteks yang khusus pula. Saya sungguh-sungguh mengafirmasi kembali bahwa "Akhmad lelah" dengan menyetujui, membuat konsensus, mengkonfirmasi, dan sebagainya. Singkatnya, saya membuat pernyataan " $p$ is true" dalam suatu konteks di mana " $p$ " sudah dibuat atau direncanakan akan dibuat. Dalam arti inilah, misalnya, Strawson mengatakan bahwa predikat "is true" lebih memiliki fungsi performatif, dengan tindak tutur menyetujui atau mengakui, daripada deskriptif.

\section{Sumbangan Khas Austin dalam "Truth"}

Lalu di mana posisi Austin dalam konstelasi ketiga teori kebenaran di atas? Terlebih dahulu akan dijelaskan secara singkat struktur argumentasi yang dibuat oleh Austin dalam artikelnya, "Truth." Austin membagi artikelnya menjadi tujuh bagian. Pertama, bagian pengantar yang menjelaskan rumitnya menjawab pertanyaan tentang "apa itu 
kebenaran?" dengan bertitik tolak dari pertanyaan Pilatus. ${ }^{30}$ Kedua, berbagai macam kemungkinan jawaban atas pertanyaan tentang makna dari pernyataan "is true and false" ("What is it that we say is true and false?"). Menurut Austin, kandidat yang paling baik untuk jawaban itu adalah pernyataan (tuturan), dan bukan kata atau kalimat. ${ }^{31}$ Ketiga, pertanyaan selanjutnya yang dibahas Austin adalah kapan suatu pernyataan itu benar ("When is a statement true?"). Di sini Austin menjelaskan beberapa macam teori kebenaran dan posisi dia sendiri di mana. ${ }^{32}$ Keempat, Austin menjelaskan mengapa ia menolak pernyataan bahwa predikat "adalah benar" secara logis berlebihan. ${ }^{33}$ Kelima, Austin memberikan beberapa alasan lain atas penolakannya itu. ${ }^{34}$ Keenam, Austin mempertanyakan apakah setiap "pernyataan" memang bertujuan untuk dinilai benar/salahnya. ${ }^{35}$ Ketujuh, Austin secara eksplisit menanggapi pandangan Strawson mengenai kebenaran: apa yang ditolaknya dan apa yang disetujuinya. ${ }^{36}$

Kalau memperhatikan sumbangan Austin yang membuka skema tuturan sehingga tidak dibatasi pada tuturan deskriptif seperti kaum positivis-logis, dengan mudah kita menduga bahwa Austin akan memilih teori deflasioner yang sudah dimodifikasi di atas. Namun kita tahu bahwa salah satu maksud dari artikel ini adalah justru untuk melawan posisi Strawson yang jelas-jelas mengambil posisi terakhir tersebut. Austin nampaknya lebih cenderung memilih bentuk tertentu teori korespondensi, seperti yang dikatakan dalam bagian ketiga artikelnya: jawaban spontan atas pertanyaan "kapan suatu pernyataan benar" adalah "ketika hal itu sesuai (berkorespondensi) dengan fakta." ${ }^{37}$ Pertanyaannya, apakah Austin sepenuhnya menerima teori korespondensi itu secara

30 Lih. John Langshaw Austin, "Truth," p. 117.

31 Lih. John Langshaw Austin, "Truth," pp. 117-121.

32 Lih. John Langshaw Austin, “Truth,” pp. 121-126.

33 Lih. John Langshaw Austin, "Truth," pp. 126-129.

34 Lih. John Langshaw Austin, "Truth," pp. 129-130.

35 Lih. John Langshaw Austin, "Truth," pp. 130-132.

36 Lih. John Langshaw Austin, "Truth," pp. 132-133.

37 John Langshaw Austin, “Truth,” p. 121. 
utuh ataukah ia hanya menerima versi tertentu dari teori korespondensi itu?

Interpretasi yang paling umum dalam teori korespondensi, menurut Graham, adalah bahwa ide korespondensi itu seperti ide "mirroring" ("mencerminkan") dunia atau "mapping" ("memetakan") dunia. Artinya, korelasi antara bahasa dan dunia dalam ide korespondensi itu seperti korelasi langsung antara hal dan yang direpresentasikan. Harus diingat bahwa sebenarnya ide "mencerminkan" atau "memetakan" dunia ini hanyalah sekedar metafora untuk menggambarkan relasi bahasa dan dunia. Akan menjadi masalah kalau metafora ini dipahami terlalu harfiah, karena selalu ada perbedaan antara halnya sendiri (dunia) dengan yang berusaha merepresentasikannya (bahasa). Namun, menurut Graham, kritik atas metafora "cermin" dan "peta" ini tidak begitu saja berarti bahwa kebenaran tidak dapat dijelaskan lewat ide korespondensi. Dalam hal ini diperlukan interpretasi baru atas ide korespondensi, karena metafora "cermin" dan "peta" itu memang dapat menyesatkan. ${ }^{38}$

Mengisi kekosongan inilah, kata Graham, yang menjadi sumbangan paling orisinal dari Austin. Austin menyarankan bahwa ide korespondensi antara tuturan yang benar dan dunia "secara absolut dan secara murni bersifat konvensional. ... Tidak perlu sama sekali bagi kata-kata untuk membuat suatu tuturan yang benar "mencerminkan" dalam bentuk apa-pun, juga kalau tidak langsung, sifat-sifat dari situasi atau kejadian..." 39 Lalu kalau korespondensi tidak berarti "mencerminkan," bentuk korespondensinya seperti apa?

Untuk menjawab pertanyaan di atas, menurut Graham, kita dapat menelusurinya dari jawaban Austin atas pertanyaan mengenai apa yang berkorespondensi dengan dunia, apa yang menjadi pembawa kebenaran yang primer. Pertanyaan ini diajukan Austin dalam bagian kedua arti-

38 Lih. Keith Graham, J. L. Austin, p. 190.

39 "Is absolutely and purely conventional. ... There is no need whatsoever for the words used in making a true statement to "mirror" in any way, however indirect, any feature whatsoever of the situation or event..." John Langshaw Austin, "Truth," pp. 124-125; penekanan berasal dari Austin. 
kelnya. Di sana ia menjawab bahwa kandidat utama untuk itu adalah suatu pernyataan (tuturan), yang dalam pendekatan filsafat bahasa sehari-hari disebut sebagai "statement-acts" ("tindak-tutur"): "suatu tuturan dibuat dan pembuatannya adalah suatu kejadian historis, pernyataan yang dibuat oleh pembicara atau penulis tertentu yang terdiri dari kata-kata (kalimat) tertentu dan diarahkan kepada pendengar dengan rujukan pada situasi, kejadian historis atau apa pun." ${ }^{40}$ Artinya, tindak-tutur yang kongkretlah yang dipilih sebagai terminologi dalam relasi korespondensi. Apakah kita lebih menyukai istilah "pernyataan" atau "tuturan" tidaklah penting. Yang penting, menurut Austin, adalah bahwa ungkapan yang kita gunakan seharusnya "memiliki kelebihan untuk merujuk secara jelas pada penggunaan historis sebuah kalimat oleh seseorang yang menggunakannya." 41

Preferensi pada hal yang konkret, menurut Graham, adalah salah satu alasan mengapa Austin memilih tuturan sebagai pembawa kebenaran yang primer. Namun ada alasan lain mengapa ia lebih memilih tuturan dari pada, misalnya, kalimat. Ini adalah alasan yang membuat kita dapat memahami apa yang dimaksud Austin dengan ide korespondensi konvensional. Beberapa filosof menyatakan bahwa kebenaran itu pertama-tama adalah milik kalimat. Austin menyatakan lebih spesifik, yakni bahwa hanyalah suatu kalimat yang digunakan oleh orang tertentu dalam kesempatan tertentu, bukan kalimat yang umum, yang dapat dinilai benar atau salah. ${ }^{42} \mathrm{Hal}$ itu adalah pernyataan atau tuturan seperti yang sudah dijelaskan dalam alasan pertama. Mengapa harus lebih spesifik? Karena orang dapat menggunakan kalimat yang satu dan sama untuk membuat pernyataan yang berbeda. Misalnya, saya dan kamu dapat mengatakan kalimat yang sama, "Tangan saya dingin." Namun salah satu dapat mengatakannya dengan benar dan lainnya salah. Maka bukan sembarang kalimat yang dapat dinilai benar atau salah, melainkan kalimat yang

40 John Langshaw Austin, "Truth," pp. 119-120.

41 John Langshaw Austin, "Truth," pp. 120-121.

42 “... sentence as used by a certain person on a certain occasion." John Langshaw Austin, "Truth," p. 119; penekanan berasal dari Austin. 
digunakan untuk membuat pernyataan tertentu.

Kita kembali pada pertanyaan, apa yang membuat suatu tuturan (pernyataan) itu benar? Dalam arti apa tuturan itu harus berkorespondensi dengan fakta? Untuk menjawab pertanyaan ini perbedaan antara tuturan dan kalimat yang telah dijelaskan di atas menjadi penting. Austin merumuskan dua konvensi yang menjadi syarat bagi suatu pernyataan untuk menjadi benar, yakni

Konvensi deskriptif yang menghubungkan kata-kata (=kalimat-kalimat) dengan tipe-tipe situasi, hal, kejadian, dan lain sebagainya yang ditemukan dalam dunia. Konvensi demonstratif yang menghubungkan katakata (=tuturan-tuturan) dengan situasi-situasi historis, dan lain sebagainya, yang ditemukan dalam dunia. Suatu tuturan dikatakan benar ketika apa yang terjadi secara historis yang dikorelasikan dengan konvensi demonstratif (sesuatu yang "dirujuk" oleh tuturan itu) adalah suatu tipe yang menggunakan kalimat yang dikorelasikan dengan konvensi deskriptif. ${ }^{43}$

Konvensi deskriptif berkaitan dengan simbol-simbol yang secara konvensional memiliki makna tertentu yang sudah disepakati bersama, simbol-simbol ini pada dasarnya dapat digunakan kembali, dapat digunakan lebih dari satu kesempatan. Sementara itu, konvensi demonstratif adalah sisi lain dari koin yang sama, yakni berkaitan dengan pemakaian simbol-simbol yang lebih umum dalam situasi yang khusus: suatu kejadian tertentu dan bukan sekedar suatu tipe kejadian yang umum. Artinya, pastilah mungkin menggunakan konteks tertentu yang dihubungkan dengan kejadian tertentu, kejadian historis. Kalimat "orang di sebelah kiri saya memakai baju biru" dihubungkan dengan suatu tipe situasi tertentu yang ditentukan oleh artinya, dan dapat digunakan dalam kesempatan yang berbeda-beda, asal memenuhi syarat

43 "... there must be two sets of convention: Descriptive conventions correlating the words (= sentences) with the types of situation, thing, event, etc., to be found in the world. Demonstrative conventions correlating the words (= sentences) with the historic situations, etc., to be found in the world. A statement is said to be true when the historic state of affairs [or e.g., situation, thing, event] to which it is correlated by the demonstrative by the demonstrative conventions (the one to which it 'refers') is of a type with which the sentence used in making it is correlated by the descriptive conventions." John Langshaw Austin, "Truth." pp. 121-122 
yang sesuai dengan maknanya. Jika dan hanya jika kalimat itu digunakan dengan cara tertentu, yakni digunakan sesuai dengan situasi yang cocok dengan tipe itu, maka kita dapat berbicara tentang tuturan yang benar. Singkatnya, suatu tuturan harus memenuhi kedua konvensi itu untuk menjadi tuturan yang dapat dinilai benar atau salah.

Sumbangan khas Austin adalah membuat interpretasi baru atas ide korespondensi dengan menekankan unsur konvensional dalam hubungan kebenaran dan dunia. Austin menganut teori korespondensi yang sudah diinterpretasikan secara baru.

\section{Penolakan Austin Terhadap Teori Deflasioner}

Selanjutnya Austin menjelaskan penolakannya atas pandangan teori deflasioner yang menyatakan bahwa "Dalam semua kalimat dalam bentuk ' $p$ adalah benar', frase 'adalah benar' itu secara logis berlebihan." ${ }^{44}$ Mengapa ia menolak hal ini? Ada dua alasan yang ia kemukakan. Pertama, karena "mengatakan bahwa suatu pernyataan itu benar adalah tidak membuat pernyataan yang lebih jauh lagi;" ${ }^{45}$ artinya, informasi yang dimuat oleh pernyataan " $p$ adalah benar" tidak berbeda dengan informasi yang dimuat oleh pernyataan " $p$." Kedua, karena "mengatakan bahwa suatu pernyataan itu benar adalah sekedar menegaskannya, dan mengatakan bahwa itu salah adalah menegaskan kebalikannya." ${ }^{46}$

Austin menguraikan argumentasinya menolak pandangan di atas. Pertama, Austin menggunakan analogi pengadilan. Kasusnya adalah masalah tuduhan Mr. Q atas Mr. W bahwa Mr. W adalah perampok. Atas kasus itu dilakukan dua macam pengadilan. Pengadilan pertama diadakan untuk membuktikan apakah pernyataan Mr. Q itu adalah suatu pencemaran nama baik. Hasilnya adalah bahwa pernyataan Mr. $\mathrm{Q}$ tentang $\mathrm{Mr}$. $\mathrm{W}$ itu ternyata benar (dalam substansi dan fakta). Kemudian pengadilan kedua diselenggarakan. Dalam pengadilan kedua ini

44 John Langshaw Austin, "Truth," p. 126.

45 John Langshaw Austin, "Truth," p. 126.

46 John Langshaw Austin, “Truth," p. 126. 
bukan pernyataan Mr. Q yang menjadi bahan pertimbangan, melainkan soal apakah Mr. W benar-benar seorang perampok. Keputusannya adalah "Mr. W adalah perampok." Dari contoh pengadilan ini Austin mengatakan bahwa predikat "adalah benar" tidaklah berlebihan secara logis. ${ }^{47}$

Berkaitan dengan alasan penolakan yang kedua Austin berpendapat bahwa dalam pandangan itu ada kerancuan antara kesalahan dan negasi. Artinya, penganut teori deflasioner seolah-olah menganggap dua pernyataan ini sama: "Ia tidak berada di rumah" dengan "Adalah salah bahwa ia di rumah." (Namun bagaimana jika tidak ada orang yang mengatakan bahwa ia ada di rumah? Bagaimana jika ia terbaring di tingkat atas dalam kondisi meninggal?). Kesalahan dan negasi adalah dua hal yang berbeda yang dalam alasan penolakan kedua dicampur-adukkan. ${ }^{48}$

Austin mengatakan bahwa alasan lain untuk menolak pandangan bahwa predikat "adalah benar" itu secara logis berlebihan. Alasan ini sekaligus dapat mengapresiasi pernyataan macam apa yang dihasilkan oleh ungkapan bahwa pernyataan tertentu itu benar. Austin menempatkan kata sifat "benar" dan "salah" dalam kategori yang sama dengan kata sifat lain yang mau menggambarkan relasi antara kata (seperti yang diungkapkan dengan merujuk pada suatu situasi historis) dan dunia. Misalnya, suatu pernyataan dapat disebut berlebihan atau tidak jelas atau datar, suatu deskripsi dapat disebut kasar atau menyesatkan atau tidak terlalu baik. Dalam situasi seperti ini, menurut Austin, "adalah tidak bermanfaat untuk menekankan pengambilan keputusan dalam arti sederhana apakah pernyataan itu 'benar atau salah.'"49 Austin mengingatkan bahwa seringkali kita terobsesi dengan "kebenaran" ketika mendiskusikan pernyataan, seperti kita terobsesi dengan "kebebasan" ketika mendiskusikan tindakan manusia. Kita harus membuka cakrawala yang lebih luas, karena "seperti kebebasan, kebenaran adalah suatu

47 Lih. John Langshaw Austin, "Truth," p. 127.

48 Lih. John Langshaw Austin, "Truth," p. 128.

49 John Langshaw Austin, “Truth," pp. 129-130. 
titik minimal yang kosong atau suatu cita-cita yang tidak nyata." 50

Dari argumentasi terakhir di atas, Austin mengajak untuk melihat lebih dalam apakah setiap "pernyataan" itu hanya bertujuan untuk mencapai kebenaran saja. Jawabannya, tentu saja tidak. Dalam hal ini Austin menunjukkan keragaman tuturan yang tidak hanya bertujuan pada benar atau salahnya tuturan seperti dalam tuturan deskriptif. Misalnya, rumusan dalam kalkulus, tuturan performatif, keputusan berkaitan dengan nilai, tuturan dalam kerangka cerita fiksi. Dalam tuturan-tuturan itu tidaklah penting bahwa apa yang dituturkan harus sesuai dengan fakta. Jika kita menyadari dan mengakui keragaman tuturan tersebut, maka kita tidak akan tergoda untuk menyebutnya "benar" atau mendiskusikan kebenaran dan kesalahannya, karena kategori ini tidak relevan. ${ }^{51}$

Akhirnya, berkaitan dengan artikel Strawson, “Truth” (1949), Austin membaginya menjadi dua bagian. Austin tidak setuju dengan bagian pertama posisi Strawson, namun mengafirmasi bagian keduanya. Bagian pertama yang ditentang oleh Austin adalah posisi Strawson yang menolak teori "semantik" kebenaran berdasarkan klaim bahwa frase "adalah benar" tidak digunakan untuk kalimat. Strawson mendukung klaim ini dengan hipotesis yang jenius bahwa makna dapat dikacaukan dengan kebenaran. Namun menurut Austin, klaim ini tidak mencukupi untuk menunjukkan bahwa frase "adalah benar" tidak digunakan untuk berbicara mengenai apa saja. Lebih jauh Strawson juga mendukung pandangan bahwa predikat "adalah benar" secara logis berlebihan, yang ditentang Austin. Namun Austin mendukung bagian kedua pendapat Strawson yang memperlihatkan keberagaman tuturan dan tidak terbatas pada pernyataan deskriptif yang harus ditentukan benar dan salahnya. ${ }^{52}$

50 John Langshaw Austin, “Truth,” p. 130.

51 Lih. John Langshaw Austin, “Truth,” pp. 130-132.

52 Lih. John Langshaw Austin, “Truth,” p. 153. 


\section{PENUTUP}

Telah kita lihat di atas bahwa Austin lebih memilih suatu versi teori korespondensi dari pada teori deflasioner yang sudah direvisi dalam konsepnya tentang kebenaran. Menurut Graham, pilihan Austin ini tidak konsisten dengan pendekatan penggunaan bahasa sehari-hari yang ditekankannya. Bagaimana tidak? Untuk mempertimbangkan masalah kebenaran mau tidak mau filosof seperti Austin akan berangkat dari hakikat bahasa. Kita tahu bahwa Austin sangat menekankan aspek ilokusioner ("the illocutionary aspects") bahasa yang terutama nampak dalam pembahasannya tentang tuturan performatif. ${ }^{53}$ Dengan demikian seharusnya ia akan memilih teori deflasioner yang telah direvisi seperti Strawson yang lebih menekankan pentingya tuturan performatif dalam analisisnya tentang kebenaran. Namun mengapa Austin justru dengan sadar lebih memilih teori korespondensi yang diintrepetasikan secara baru dengan memasukkan unsur konvesionalitas? ${ }^{54}$ Seperti kita ketahui salah satu tujuan artikelnya adalah untuk melawan Strawson yang terlalu menekankan fungsi performatif dalam konsep kebenarannya. Graham mengatakan dengan lugas tentang anomali yang dilakukan Austin: "Saya yakin masalah kebenaran adalah masalah yang membuat dua bagian yang berbeda dari filsafat Austin mendorongnya ke dua arah yang berbeda." 55

Menurut penulis, setidak-tidaknya ada empat alasan menarik yang dikemukakan Graham atas terjadinya ketidak-konsistenan atau anomali ini pada Austin. Pertama, Graham berpendapat bahwa teori ilokusioner pada umumnya tidak mampu menjawab masalah-masalah filosofis yang klasik seperti kebenaran. Maka, mungkin memang lebih baik Austin

53 Austin membicarakan tentang aspek ilokusioner (the illocutionary aspect) bahasa untuk menunjukkan bahwa mengatakan sesuatu dapat berarti melakukan sesuatu. Seseorang mungkin melakukan sesuatu dalam mengatakan sesuatu, atau melakukan apa yang disebut Austin "illocutinary act" (tindakan ilokusioner). Analisis aspek ilokusioner ini memegang peranan sangat penting dalam "teori tindak-tutur" (speech-act theory)-nya. Analisis aspek ilokusioner bahasa ini merupakan perluasan dari analisis mengenai tuturan performatif. Lih. Keith Graham, J. L. Austin, p. 88.

54 Lih. Keith Graham, J. L. Austin, pp. 188, 211-212.

55 Keith Graham, J. L. Austin, pp. 188-189. 
menghindar dari pendekatan yang kalau konsisten dilakukannya justru ter-bukti tidak mampu menjawab masalah itu. Namun, ada dua alasan lain yang menurut Graham lebih penting dari yang pertama. ${ }^{56}$

Kedua alasan lain ini, menurut Graham, bertitik tolak dari pengakuan Austin secara eksplisit dalam artikel ini mengenai beberapa kelemahan dalam suatu analisis ilokusioner terhadap suatu konsep. Pertama, Austin mengakui bahwa kekuatan ilokusioner hanyalah salah satu aspek dari suatu pernyataan: untuk melakukan suatu tindak-tutur seseorang mungkin perlu menambahkan beberapa label yang lebih umum, seperti "menghina" atau "mengkonfirmasi." Namun hal ini sepenuhnya selaras dengan secara bersama-sama mengatakan sesuatu yang pada dirinya sendiri mampu memiliki kebenaran atau kesalahan (tuturan deskriptif). Kedua, Austin mengakui bahwa suatu analisis ilu-kusioner sangat mungkin menghasilkan alasan untuk menerapkan konsep dalam berbicara. Namun analisis ini tidak mengatakan apa-apa kepada kita mengenai konteks, di mana, misalnya, aku melihat konsep itu berlaku, namun aku tidak mengatakan apa-apa. ${ }^{57}$

Alasan terakhir berkaitan dengan fakta bahwa Austin tidak menggunakan analisis ilokusioner sebagai analisis bahasa dalam pembahasan mengenai kebenaran. Graham menyatakan bahwa Austin tidak menggunakan analisis ilokusioner atau tuturan performatif, karena ia tidak sedang membicarakan bermacam-macam penggunaan kreatif bahasa yang memang merupakan kekuatan analisis ini. Pada saat membicarakan masalah kebenaran, Austin sadar bahwa ia mendiskusikan apa yang secara tradisional diterima sebagai satu-satunya penggunaan bahasa, penggunaannya untuk merefleksikan hakikat realitas yang telah ada sebelumnya. Maka di sini analisis ilokusioner tidak relevan untuk digunakan..$^{58}$

56 Lih. Keith Graham, J. L. Austin, p. 212.

57 Lih. Keith Graham, J. L. Austin, p. 212.

58 Lih. Keith Graham, J. L. Austin, pp. 212-213. 
Berdasarkan alasan terakhir inilah, menurut penulis, terlihat jelas mengapa dalam pembahasan tentang kebenaran Austin tidak mengikuti gaya Strawson yang menggunakan teori deflasioner. Dalam artikel “Truth" Austin dengan tegas mengkritik teori deflasioner Strawson yang sebenarnya lebih konsisten menerapkan analisis aspek ilokusioner bahasa yang nampak dalam tuturan performatif. Dengan tegas Strawson berbicara mengenai kesalahan deskriptif para lawannya, karena mereka mengira bahwa tuturan yang mereka analisis adalah tuturan deskriptif, padahal sebenarnya hal itu adalah tuturan performatif.

Bertolak belakang dengan Strawson, Austin lebih memilih untuk menggunakan teori korespondensi dalam membahas masalah kebenaran. Namun Austin tidak begitu saja menggunakan teori korespondensi umum seperti nampak dalam ide korespondensi sebagai "pencerminan" atau "pemetaan" dunia; artinya, dalam ide korespondensi seperti ini korelasi antara bahasa dan dunia seperti korelasi langsung antara tanda dengan apa yang direpresentasikan. Austin mengingatkan bahwa istilah "cermin" atau "peta" sebenarnya hanya metafora untuk menunjukkan korelasi antara bahasa dan dunia yang tidak dapat dipahami secara harfiah, karena bahasa dan dunia tidak sama dan sebangun; maka perlu interpretasi baru atas ide korespondensi tersebut agar kebenaran dapat dijelaskan dengan teori korespondensi.

Dalam menginterpretasikan secara baru ide tentang korespondensi inilah terlihat sumbangan Austin yang khas untuk membahas masalah filosofis klasik mengenai kebenaran. Austin memasukkan unsur konvensional di dalam ide korespondensi. Artinya, ide korespondensi antara tuturan yang benar dengan dunia "secara murni dan absolut bersifat konvensional." 59 Lebih spesifik lagi ia mengatakan bahwa hanyalah kalimat yang digunakan oleh orang tertentu dalam kesempatan tertentu, bukan sebuah kalimat yang umum, yang dapat dinilai sebagai suatu tuturan yang benar atau salah. Hal ini kemudian dijelaskannya sebagai gabungan antara konvensi deskriptif dan demonstratif. Yang pertama

59 John Langshaw Austin, “Truth,” p. 124. 
berkaitan dengan simbol-simbol yang secara konvensional disepakati bersama memiliki makna tertentu dan bisa digunakan berulang-ulang. Sedangkan yang kedua menunjuk pada pemakaian simbol-simbol tersebut pada suatu situasi historis tertentu.

Interpretasi baru Austin atas ide korespondensi sebagai sesuatu yang bersifat konvensional adalah sumbangan khasnya dalam memahami masalah kebenaran. Teorinya mengenai dua macam konvensi linguistik dan bagaimana peran keduanya dalam membuat pernyataan merupakan suatu usaha untuk mengartikan mengapa orang, misalnya, mengatakan sesuatu itu "sesuai dengan fakta." Ini adalah suatu usaha yang serius dan berguna untuk mengatakan sesuatu mengenai bagaimana secara umum kita dapat bergerak dari bahasa menuju pada dunia, bagaimana kita dapat menggunakan simbol-simbol bahasa yang ditentukan secara sewenang-wenang untuk merepresentasikan realitas dunia. Masalah klasik mengenai kebenaran didekati Austin dengan menggunakan ide korespondensi yang bersifat konvensional.

\section{DAFTAR RUJUKAN}

Austin, John Langshaw. How to Do Things with Words, eds. J. O. Urmson \& Marina Sbisà. Oxford: Oxford University Press, 1962. . Philosophical Papers, eds. J. O. Urmson. \& G. J. Warnock. $2^{\text {nd }}$ ed. Oxford: Oxford University Press, 1970.

. "A Plea for Excuses: The Presidential Address." In Philosophical Papers, ed. John Langshaw Austin. Oxford: Oxford Univer-sity Press, 1970, pp. 175-204.

. Sense and Sensibilia. edited by G. J. Warnock. Oxford: Oxford University Press, 1962.

. "Truth." Proceedings of the Aristotelian Society, Supplementary 24 (1950): 111-128. Reprinted in Philosophical Papers, ed. John Langshaw Austin. Oxford: Oxford University Press, 1970: 117-133.

Berlin, I. et al. Essays on J. L. Austin. Oxford: Clarendon Press, 1973.

Graham, Keith. J. L. Austin: A Critique of Ordinary Language Philosophy. Hassocks, Susssex: The Harvester Press, 1977.

Hacker, P. M. S. “Analytic Philosophy: what, whince, and whither?" In 
The Story of Analytic Philosophy: Plot and Heroes, eds. A. Biletzki \& A. Matar. London: Routledge, 1998, pp. 3-34.

Hampshire, Stuart. “J. L. Austin (1911-1960)." Proceedings of the Aristotelian Society, New Series 60 (1959-1960): I-XIV.

Lacey, Nicola. A Life of H. L. A. Hart: The Nightmare and the Noble Dream. Oxford: Oxford University Press, 2004.

Longworth, Guy. "John Langshaw Austin." In The Stanford Encyclopedia of Philosophy (Summer Edition, 2013), ed. Edward N. Zalta. http:/ /plato.stanford.edu/archives/sum2013/entries/austinj1/. Diakses pada 10 September 2013.

McCormick, Neil. H. L. A. Hart. $2^{\text {nd }}$ ed. Stanford: Stanford University Press, 2008.

Searle, John R. “J. L. Austin (1911-1960)." In A Companion to Analytic Philosophy, , eds. A. P. Martinich \& D. Sosa. Oxford: Blackwell, 2001: 218-230.

- Speech Acts: An Essay in the Philosophy of Language. Cambridge: Cambridge University Press, 1969.

Stoljar, Daniel \& Nic Damnjanovic. "The Deflationary Theory of Truth.” In The Stanford Encyclopedia of Philosophy (Summer Edition, 2012), ed. Edward N. Zalta. http://plato.stanford.edu/archives/ sum2012/entries/truth-deflationary/. Diakses pada 10 September 2013.

Strawson, P. F. “Truth." Analysis 9 (June, 1949): 83-97.

. "Truth." Proceedings of the Aristotelian Society, Supplementary 24 (1950): 129-156.

Warnock, G.J. "Saturday Mornings." In Essays on John Langshaw Austin, eds. I. Berlin et al. Oxford: Oxford University Press, 1973: 31-45.

Weitz, Moritz. "Oxford Philosophy." The Philosophical Review 62 (1953): 187-233. 